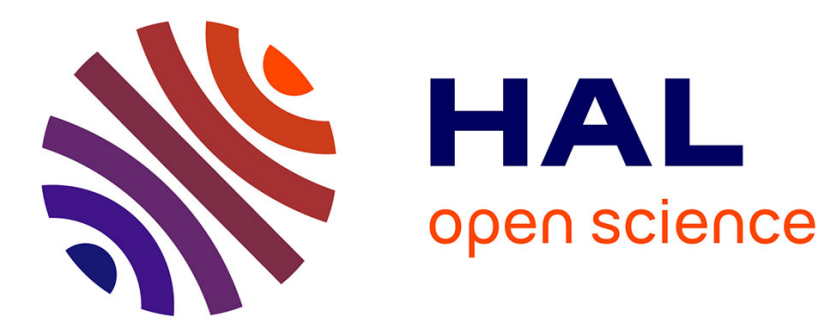

\title{
Fiscal Sustainability in the Presence of Systemic Banks: the Case of EU Countries
}

Agnès Bénassy-Quéré, Guillaume Roussellet

\section{To cite this version:}

Agnès Bénassy-Quéré, Guillaume Roussellet. Fiscal Sustainability in the Presence of Systemic Banks: the Case of EU Countries. 2012. hal-00962455

\section{HAL Id: hal-00962455 \\ https://hal-pse.archives-ouvertes.fr/hal-00962455}

Preprint submitted on 21 Mar 2014

HAL is a multi-disciplinary open access archive for the deposit and dissemination of scientific research documents, whether they are published or not. The documents may come from teaching and research institutions in France or abroad, or from public or private research centers.
L'archive ouverte pluridisciplinaire HAL, est destinée au dépôt et à la diffusion de documents scientifiques de niveau recherche, publiés ou non, émanant des établissements d'enseignement et de recherche français ou étrangers, des laboratoires publics ou privés. 


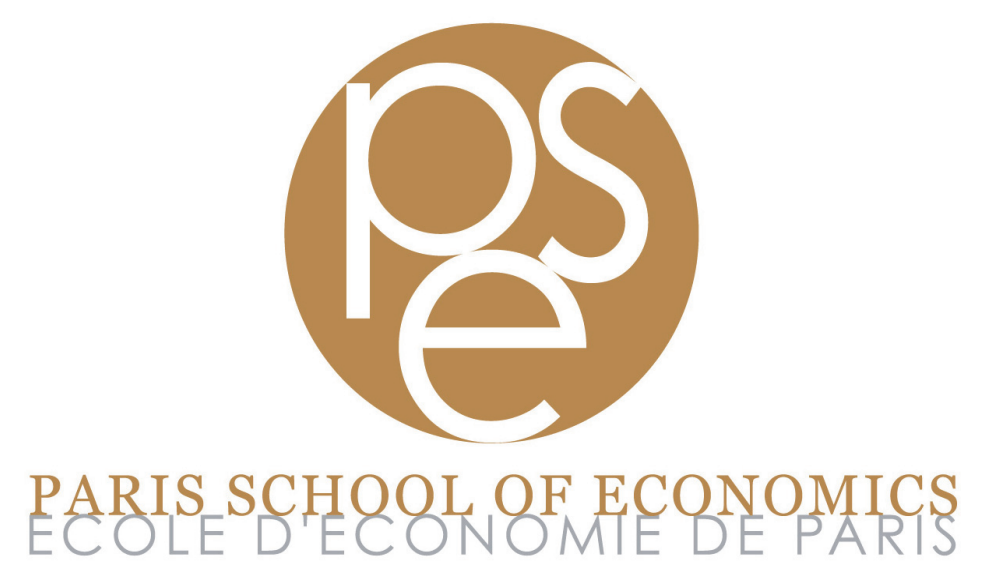

Fiscal Sustainability in the Presence of Systemic Banks: the Case of EU Countries

\section{G-MonD

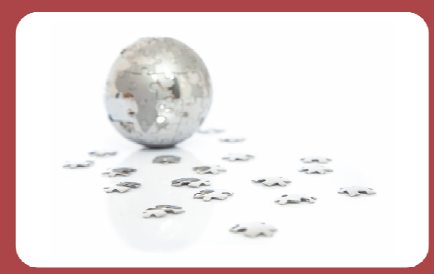 \\ Working Paper n`24}

For sustainable and inclusive world development 


\title{
Fiscal Sustainability in the Presence of Systemic Banks: the Case of EU Countries*
}

\author{
Agnès Bénassy-Quérétand Guillaume Roussellet ${ }^{\ddagger}$
}

March 2012

\begin{abstract}
We provide a first attempt to include off-balance sheet, implicit insurance to SIFIs into a consistent assessment of fiscal sustainability, for 27 countries of the European Union. We first calculate tax gaps à la Blanchard (1990) and Blanchard et al. (1990). We then introduce two alternative measures of implicit off-balance sheet liabilities related to the risk of a systemic bank crisis. The first one relies of microeconomic data at the bank level. The second one relies on econometric estimations of the probability and the cost of a systemic banking crisis, based on historical data. The former approach tends to maximize the fiscal cost of systemic banking crises, whereas the latter one tends to minimize it. Hence we believe that the combined use of these two methodologies helps to gauge the range of fiscal risk.
\end{abstract}

JEL: H21, H23, J41

Keywords: Fiscal sustainability, systemic banking risk, off-balance sheet liabilities.

\footnotetext{
${ }^{*}$ We are grateful to Gunther Capelle-Blancard, Julien Matheron and the participants in seminars at CEPII and INSEE, for their remarks on a preliminary draft. All errors remain ours.

${ }^{\dagger}$ Paris School of Economics-University Paris 1 and CEPII (agnes.benassy@cepii.fr), corresponding author.

‡ENSAE (guillaume.roussellet@ensae.fr).
} 


\section{Introduction}

In the wake of the 2007-09 global crisis, advanced economies suffered dramatic deteriorations of their fiscal balances, due to bank bail outs, fiscal stimulus packages and the action of automatic stabilizers. In the Euro area, this deterioration triggered a severe sovereign debt crisis. Still, prior to the crisis, a number of European countries such as Ireland and Spain had been praised for fiscal discipline. The brutal change of status from best to worst in class has questioned traditional analyses of fiscal sustainability. The Stability and Growth Pact (SGP) has been revamped to account for excess leverage in the private sector and cumulated losses in competitiveness. In times of a financial crisis, the government is obliged to bail out the so-called Systemically Important Financial Institutions (SIFIs), whose failure would put the whole financing system at risk. As theoretized by Acharya et al. (2011), bank bailouts in turn lead to an increase in taxes and/or a dilution of existing government debt holders. In both cases, there are negative feedback effects on the banking sector through lower growth and collateral damage. Hence there is a strong interplay between bank and sovereign solvency.

To our knowledge, though, there has been little attempt to measure the implications of off-balance sheet liabilities related to SIFIs within a consistent analysis of government sustainability. One exception is the European Commission (2011) that, based on a model of bank default combined with data from Bankscope and a standard statistical model of credit risk, simulates the probability that fiscal sustainability is put at risk. The task is however extremely difficult given the lack of clarity surrounding the definition of SIFIs, and the fragility of any evaluation of the fiscal cost in case of a bail out. Last but not least, the probability of a systemic banking crisis is difficult to evaluate.

This paper provides an attempt to include off-balance sheet, implicit insurance to SIFIs into a consistent assessment of fiscal sustainability, for the 27 countries of the European Union. We successively consider a micro and a macroeconomic approach. The microeconomic approach relies on the stress tests released by the European Banking Authority (EBA) in July 2011 for 90 "systemic" banks. Alternatively, we use a measure of bank capital shortage in the event of a financial crisis provided by the Volatility Laboratory of New York University. As for the macroeconomic approach, it is based on historical data on the fiscal cost of systemic banking crises. In both cases, we incorporate implicit liabilities related to a banking crisis to a standard calculation of tax gaps à la Blanchard (1990) and Blanchard et al. (1990). Contrasting with European Commission (2011), we are not interested in the probability that the tax gap exceeds a certain threshold but on the impact of implicit liabilities on the tax gap itself. More importantly, we consider the banking risk as a repeated risk, whereas European Commission (2011) focuses on stochastic shocks at one point of time.

Depending on the measure of the costs (either micro or macro) and on the data source, we find contrasted impact of the banking risk on the tax gap of the different countries under review, ranging from a few tenths of percentage 
points (macro-base approach for "old" member states) to several percentage points (micro-based, EBA approach). In between, the micro-based (V-Lab) approach suggests that systemic banking risk could raise tax gaps by around one percentage point.

The remainder of the paper is organized as follows. In Section 2, we present the concept of fiscal sustainability and its operationalization through the tax gap, with an application to EU countries. Section 3 discusses the measurement of contingent liabilities related to SIFIs and proposes a first, micro-based correction of the tax gaps. In Section 4, we develop a macro-based approach of contingent liabilities related to SIFIs and propose an alternative, macro-based correction of the tax gaps, relying on two, complementary sets of econometric estimations. Section 5 concludes.

\section{Fiscal sustainability: from theory to practice}

Fiscal sustainability refers to the ability of current or projected fiscal policy to be run infinitely given the macroeconomic path of a country. The literature has followed two main avenues to operationalize this concept. First, it has used econometric techniques and especially cointegration to determine whether past fiscal policies can be considered sustainable (see Hamilton \& Flavin (1986)). The second approach intends to assess fiscal sustainability forward, based on fiscal and growth projections and on the debt accumulation process. Because it relates to the possibility of rare events - the advent of a systemic banking crisis - our approach needs to lie within the second strand of the literature.

\subsection{Fiscal sustainability in theory}

The first formalization of fiscal sustainability is due to Domar (1944). Consider the following debt accumulation process:

$$
B_{t}=B_{0}+\alpha Y_{0} \int_{0}^{t} e^{\gamma u} \mathrm{~d} u=B_{0}+\frac{\alpha Y_{0}}{\gamma}\left(e^{\gamma t}-1\right)
$$

where $B_{t}$ is the level of public debt at time $t, Y_{t}$ denotes nominal national revenue, $\alpha$ is the constant deficit ratio (including interest payments), and $\gamma$ represents the nominal growth rate, also considered constant. The debt-to-GDP ratio at time $t$ then writes:

$$
\frac{B_{t}}{Y_{t}}=\frac{B_{0}}{Y_{0} e^{\gamma t}}+\frac{\alpha}{\gamma}\left(1-e^{-\gamma t}\right)
$$

In the long run, the debt-to-GDP ratio converges to a finite value that depends positively on the deficit ratio $\alpha$ and negatively on the nominal growth

rate $\gamma$ :

$$
\lim _{t \rightarrow+\infty} \frac{B_{t}}{Y_{t}}=\frac{\alpha}{\gamma}
$$


Fiscal sustainability is obtained thanks to the assumption of a constant deficit ratio $\alpha$ whatever happens to interest payments. Blanchard (1990) and Blanchard et al. (1990) have refined the Domar (1944)'s framework by introducing a time-varying budget deficit and disentangling interest payments. Using the same notations as before and denoting by $S_{t}$ the primary surplus and by $r$ the nominal interest rate, we have:

$$
\frac{\mathrm{d} B_{t}}{\mathrm{~d} t}=r B_{t}-S_{t}
$$

Denoting by lower cases the government debt and the primary balance in percent of GDP (i.e. $b_{t} \equiv \frac{B_{t}}{Y_{t}}$ and $\left.s_{t} \equiv \frac{S_{t}}{Y_{t}}\right)$ we get:

$$
\frac{\mathrm{d} b_{t}}{\mathrm{~d} t}=(r-\gamma) b_{t}-s_{t}
$$

Hence:

$$
b_{t}=b_{0} e^{(r-\gamma) t}-\int_{0}^{t} s_{u} e^{(r-\gamma)(t-u)} \mathrm{d} u
$$

Multiplying each side of Equation $(6)$ by $e^{-(r-\gamma) t}$, we get:

$$
b_{t} e^{-(r-\gamma) t}=b_{0}-\int_{0}^{t} s_{u} e^{-(r-\gamma) u} \mathrm{~d} u
$$

Equation (7) states that the present value of $b_{t}$ at time 0 is equal to the current value of the debt minus the sum of all present values of primary surpluses from time 0 to time $t$. Considering the standard case where $r>\gamma$, debt sustainability involves both sides of the equation to converge to zero when $t$ goes to infinity: ${ }^{1}$

$$
\lim _{t \rightarrow+\infty} b_{t} e^{-(r-\gamma) t}=0 \Leftrightarrow b_{0}=\int_{0}^{\infty} s_{u} e^{-(r-\gamma) u} \mathrm{~d} u
$$

The left hand-side condition is the transversality condition. ${ }^{2}$ It states that the debt-to-GDP ratio should grow at a slower pace than the gap between the interest rate and the GDP growth rate. The second condition states that the interest payments on the current debt should be fully covered by future primary surpluses. A sustainability indicator can then be derived from this second condition through decomposing the primary surplus as follows: $s_{t}=$ $\tau_{t}-g_{t}-h_{t}$ with $\tau_{t}$ the tax rate, $g_{t}$ government spending in goods and services, and $h_{t}$ public transfers (in percent of GDP). Considering $r$ and $\gamma$ as exogeneous, the sustainable tax rate $\tau^{*}$ is the constant tax rate that ensures debt sustainability, given projected expenditures:

\footnotetext{
${ }^{1}$ When $r<\gamma$, an ever-rising primary deficit is consistent with the debt ratio not rising infinitely. Following Blanchard, we exclude this dynamic inefficiency case and assume $r>\gamma$.

${ }^{2}$ Also labeled actuarial sustainability or no Ponzi game condition.
} 


$$
\tau^{*}=(r-\gamma)\left(b_{0}+\int_{0}^{\infty}\left(g_{u}+h_{u}\right) e^{-(r-\gamma) u} \mathrm{~d} u\right)
$$

$\tau^{*}$ can be compared to the current tax rate to assess fiscal sustainability. For instance, $\tau^{*}>\tau$ implies that the current policy cannot be run forever, so either spending will have to be cut, or the tax rate will have to be raised.

One important limitation of this approach is the assumption of exogenous interest and growth rates. On the one hand, the interest rate paid on government debt may react to the debt sustainability assessment itself, leading to multiple equilibria. On the other hand, fiscal unsustainability may be achieved thanks to excess spending that maintains GDP growth at an artificially high level. However, both arguments tend to compensate each other. For instance, in case of unsustainability, both the interest rate and the growth rate may be higher than under a sustainable path, with ambiguous effect on the difference between the two.

More fundamentally, Bohn (1995) argues that future government revenues and expenditures should not be discounted by a fixed interest rate on government (safe) bonds, but rather by the variable intertemporal marginal rate of substitution, that may be correlated with fiscal variables. However he confesses that such approach is difficult to carry out in practice.

Finally, it should be noted here that by substracting nominal growth from the nominal interest rate in the discount factor $r-\gamma$, we exclude the possibility that intertemporal sustainability is achieved through an inflation tax. In the following, both nominal variables will be replaced by real ones, consistent with the Fisher effect.

\section{$2.2 \quad$ Fiscal sustainability in practice}

Calculating sustainable tax rates as defined above would require projections of public spending at an infinite horizon. To make the concept operational, Blanchard (1990) and Blanchard et al. (1990) propose the following finite-horizon equivalent of $\tau^{*}$ :

$$
\tau_{T}^{*}=(r-\gamma)\left(\left(1-e^{-(r-\gamma) T}\right)^{-1} \int_{0}^{T}\left(g_{u}+h_{u}\right) e^{-(r-\gamma) u} \mathrm{~d} u+b_{0}\right)
$$

where $T$ is the horizon of the indicator $(1,5$ or 40 years in Blanchard et al. (1990)). The equivalent in discrete time is:

$\tau_{T}^{*}=\frac{r-\gamma}{1+r-\gamma}\left(\left(1-\frac{1}{(1+r-\gamma)^{T}}\right)^{-1}\left(\sum_{u=1}^{T}\left(\frac{1}{1+r-\gamma}\right)^{u-1}\left(g_{u}+h_{u}\right)\right)+b_{0}\right)$

where $b_{0}$ is the debt-to-GDP ratio at the end of the initial period, and $g_{u}$, $h_{u}$ denote flows of expenditures over each period $u(u=1$ to t). We can check 
that $\lim _{T \rightarrow+\infty} \tau_{T}^{*}=\tau^{*}$, i.e. the finite-horizon indicator converges to the infinite one when $T$ goes to infinity. The tax gap at horizon $T$ is then the difference between the sustainable tax level $\tau_{T}^{*}$ and the present tax level $\tau_{t}$. A positive tax gap means that either expenditures need to be reduced or taxes need to be raised to meet the sustainability condition.

The intuition of Equation (11) can be grasped by assuming constant public spending in percentage of GDP over the entire $T$ period $\left(g_{t}+h_{t}=g_{T}+h_{T}=c s t\right.$ for $t=0$ to $T$ ). Equation (11) then boils down to:

$$
\tau_{T}^{*}=g_{T}+h_{T}+\frac{r-\gamma}{1+r-\gamma} b_{0}
$$

The sustainable tax rate is the one that covers both primary expenditures and the share of interest payments that is not absorbed by GDP growth, so that the public debt ratio stays constant. In a dynamic framework where government expenditures vary over time, the debt ratio is not constant but it tends to fall back to its initial level. Hence, such approach is intrinsically conservative, since the initial level of debt may not be optimal. The European Commission (European Commission (2009)) has developed a variant of above calculations aiming at measuring the fiscal consolidation that would be necessary to bring the debt-to-GDP ratio to 60 percent in 2060 (S1), and another one that would just stabilise the debt ratio while accounting for ageing cost even beyond 2060 (S2).

In the following, we calculate tax gaps at the 1, 4 and 50-year horizon, successively. Following Blanchard (1990), we neglect the discount factor $1 /(1+$ $r-\gamma)$ for the one-year and the four-year horizons. For these two horizons, the time path of $g_{t}+h_{t}$ is then irrelevant and the sustainable tax gap is recovered simply as:

$$
\tau_{T}^{*}=\bar{g}_{T}+\bar{h}_{T}+\frac{r-\gamma}{1+r-\gamma} b_{0}
$$

where $\bar{g}_{T}$ and $\bar{h}_{T}$ denote average expenditures over the $T$-year horizon $(T=$ $1,4)$. At the 50-year horizon, the discount factor can no longer be neglected and we apply Equation (11).

\subsection{Tax sustainability gaps: an application to EU coun- tries}

To calculate tax gaps at the various horizons for year 2011, we rely on various publications of the European Commission and use Maastricht definitions of deficits and debts: ${ }^{3}$

\footnotetext{
${ }^{3}$ Accordingly, general government debt is defined as the total of gross debts at face value, at the end of the current year. Unlike national accounts, Maastricht accounting consolidates the debts of the various government sub-sectors. Note that currency and deposits are included as liabilities of the central banks, but equity and derivatives are excluded from the Maastricht definition of government debt. However, the streams of interest payments related to derivatives are included in the measure of the deficit. The government debt variation then is the sum
} 
- For the 1-year horizon, we rely on EC's Economic Forecasts of the Autumn 2011. From this source we directly take the gross debt-to-GDP ratios at end 2010 and the primary balance in $2011 .{ }^{4}$ Based on interest expenditure in 2011 and the debt ratio at end 2010, we recover the implicit interest rate on the debt (interest payments in 2011/debt at end 2010). We also use real GDP growth and GDP-deflator growth in 2011.

- For the 4-year horizon, we use Convergence and Stability reports available in 2011. The reports provide fiscal and economic projections prepared by each Member state within the Stability and growth pact procedure. From these reports we recover projected deficits, growth and inflation rates for years 2011 to 2014 . Like in the previous case, we recover the implicit interest rate on the debt by dividing projected interest expenditures of year $t$ by the debt level at the end of $t-1$. For consistency, we do not mix these data with more recent EC forecasts, except for the end-2010 debt ratio and the 2011 government receipt ratio that are taken from Autumn 2011 forecasts. ${ }^{5}$ Note that Convergence and Stability reports are biased in an optimistic way since they are designed to comply with the budget balance requirement of the SGP in the medium term.

- For the 50-year horizon, we rely on the same data as above up to 2014, and on interpolations from Public Finances in EMU 2009 and the Ageing Report 2009 (baseline scenario) for 2015-2060. These two reports provide public spending ratios (including ageing-related expenditures) on a decade-by-decade basis, and the Ageing Report also provides average growth rates from 2010 to 2060 . Like for the 1-year and 4-year horizons, we also rely on the end-2010 debt ratio and the projected receipt ratio for 2011 taken from EC's forecasts of Autumn 2011. Finally, we follow the European Commission (Sustainability Report 2009) in assuming a real interest rate of 3 percent from 2015 to 2060 . We successively consider two scenarios: in the first, "on the fly" scenario, public expenditures excluding interest payments and age-related spending are supposed to stay constant in percentage of GDP from 2015 to 2060. In the second, "adjustment" scenario, public spending excluding interest payments are assumed constant over the same period, hence the rise in age-related expenditures is compensated by spending cuts in other areas.

The different tax gaps obtained are reported in Table 1, together with $r-\gamma$ gaps at the corresponding horizons. The table also reports the end-2010 debt ratio and the tax gaps obtained by the IMF (Intgernational Monetary Fund

of net borrowing by the general government and of the net purchase of financial assets. It is adjusted for the variation of non-Maastricht liabilities, capital gains or losses and miscellaneous items.

4 including non-tax receipts that are here considered a perfect substitute for tax receipts.

${ }^{5}$ The calculation of the implicit interest rate only relies on convergence and stability reports but the updated debt ratio is used as the starting point of the snowball calculations. Likewise, the updated tax ratio is only used to compare the sustainable tax ratio to the observed one. 
(2011)) when requiring the debt ratio not to exceed 60 percent of GDP at the 2020 horizon; and the European Commission, "S2" tax gap that stabilizes the debt ratio (European Commission (2010)). 
Table 1: Gap between the sustainability tax rate and the observed, implicit tax rate in 2011, in percent

\begin{tabular}{|c|c|c|c|c|c|c|c|c|c|c|}
\hline \multirow[t]{2}{*}{ Country } & \multicolumn{2}{|c|}{ Tax gap } & \multicolumn{2}{|c|}{ Tax gap } & \multicolumn{3}{|c|}{ Tax gaps } & \multirow[b]{2}{*}{$b_{2010}$} & \multirow[b]{2}{*}{$\begin{array}{c}\text { IMF } 2011 \\
10 \text { years }\end{array}$} & \multirow[b]{2}{*}{$\begin{array}{c}\text { EC } 2010 \\
\text { I(S2) }\end{array}$} \\
\hline & 1 year & $\begin{array}{c}r-\gamma \\
(1 \text { year })\end{array}$ & 4 years & $\begin{array}{c}r-\gamma \\
(4 \text { years })\end{array}$ & $\begin{array}{l}50 \text { years } \\
\text { On the fly }\end{array}$ & $\begin{array}{c}50 \text { years } \\
\text { Adjustment }\end{array}$ & $\begin{array}{c}r-\gamma \\
\text { (50 years) }\end{array}$ & & & \\
\hline $\mathrm{AT}$ & -0.1 & -1.4 & 0.2 & -0.2 & 2.2 & 0.5 & 1.3 & 71.8 & 3.4 & 4.6 \\
\hline $\mathrm{BE}$ & -0.6 & -1.0 & -0.5 & -0.2 & 2.4 & -0.4 & 1.2 & 96.2 & 2.8 & 6.5 \\
\hline BG & 1.2 & -3.1 & 0.4 & -2.1 & 1.8 & -0.7 & 1.1 & 16.3 & 1.0 & 2.8 \\
\hline CY & 4.6 & 0.5 & 1.1 & -0.8 & 3.9 & 0.4 & 0.2 & 61.5 & $\mathrm{n} / \mathrm{a}$ & 12.5 \\
\hline $\mathrm{CZ}$ & 3.1 & 1.2 & 3.3 & -0.4 & 2.8 & 1.7 & 1.2 & 37.6 & 3.4 & 9.8 \\
\hline DK & 3.0 & 1.9 & 0.8 & 0.8 & -3.0 & -0.3 & 1.3 & 43.7 & 2.0 & -1.4 \\
\hline $\mathrm{EE}$ & -1.5 & -8.4 & -1.5 & -3.0 & -6.0 & -4.1 & 0.9 & 6.7 & -3.9 & 1.2 \\
\hline FI & -1.5 & -3.2 & -2.2 & -1.7 & 1.6 & -1.0 & 1.3 & 48.3 & 1.1 & 4.3 \\
\hline FR & 3.5 & 0.4 & 0.2 & -0.5 & 1.2 & 0.2 & 1.2 & 82.3 & 6.3 & 1.0 \\
\hline $\mathrm{DE}$ & -1.7 & -0.7 & -2.4 & 0.4 & -0.4 & -2.3 & 1.8 & 83.2 & 2.3 & 4.5 \\
\hline EL & 15.0 & 8.5 & 3.9 & 3.7 & 3.8 & -2.4 & 1.2 & 144.9 & 15.5 & 20.3 \\
\hline $\mathrm{HU}$ & -6.6 & 1.2 & -11.7 & -0.3 & -12.3 & -13.0 & 1.3 & 81.3 & 1.9 & -1.3 \\
\hline IE & 10.2 & 3.7 & 3.8 & 1.7 & 2.5 & -0.8 & 0.6 & 94.9 & 12.0 & 14.8 \\
\hline IT & 1.7 & 2.3 & -0.5 & 1.3 & -0.4 & -0.8 & 1.6 & 118.4 & 3.1 & 2.6 \\
\hline LV & 0.6 & -4.1 & -1.8 & -1.1 & -4.4 & -5.3 & 1.2 & 44.7 & 2.5 & 9.0 \\
\hline LT & 1.4 & -4.8 & 1.3 & -1.9 & -2.4 & -1.0 & 1.2 & 38.0 & 4.9 & 10.4 \\
\hline $\mathrm{LU}$ & -0.1 & -1.0 & -3.2 & -3.4 & 5.0 & -3.0 & 0.3 & 19.1 & $\mathrm{n} / \mathrm{a}$ & 12.7 \\
\hline MT & -0.1 & 0.1 & -0.7 & 0.1 & 4.1 & -1.1 & 1.3 & 69.0 & $\mathrm{n} / \mathrm{a}$ & 6.4 \\
\hline NL & 2.3 & -0.1 & 0.1 & 0.7 & 5.3 & 0.0 & 1.5 & 62.9 & 4.4 & 8.5 \\
\hline PL & 1.7 & -1.9 & 0.0 & -1.5 & -0.6 & -0.1 & 1.3 & 54.9 & 6.9 & 5.6 \\
\hline PT & 6.2 & 4.9 & 1.1 & 3.4 & -1.3 & -2.4 & 1.2 & 93.3 & 9.6 & 8.9 \\
\hline RO & 2.9 & -0.7 & 1.1 & -2.5 & 3.2 & 1.5 & 1.0 & 31.0 & 4.3 & 9.7 \\
\hline SK & 3.4 & -2.3 & -0.7 & -2.3 & 5.5 & -1.3 & 1.0 & 41.0 & 6.6 & 8.5 \\
\hline SI & 5.2 & 3.5 & 0.2 & 0.9 & -1.9 & -1.8 & 1.4 & 38.8 & 4.0 & 12.2 \\
\hline $\mathrm{ES}$ & 5.3 & 1.3 & 2.3 & 0.3 & 4.7 & 1.2 & 1.1 & 61.0 & 8.3 & 15.3 \\
\hline $\mathrm{SE}$ & -3.0 & -3.4 & -4.3 & -1.9 & -5.9 & -4.4 & 1.1 & 39.7 & -0.5 & 0.5 \\
\hline UK & 6.5 & 0.3 & -2.0 & -1.1 & 0.0 & -2.4 & 0.9 & 79.9 & 9.1 & 13.5 \\
\hline
\end{tabular}

Notes: "one-the-fly": constant non-ageing expenditures in percent of GDP; "adjustment": adjusted non-ageing expenditures; $b_{2010}$ : debt ratio at end-2010; $r-\gamma$ : average value of $r-\gamma$ at the corresponding horizon. IMF 2011: debt-to-GDP ratio back to 60 percent for countries above this figure in 2012; debt ratio stabilized at its end-2012 ratio for the other countries (Fiscal Monitor2011). EC 2010 (EC): debt ratio stabilized at an infinite horizon (Public Finances in EMU 2010). n/a: non-available.

Source: Author's calculations based on European Commission data. 
At the one-year horizon, tax gaps are positive in 18 countries (meaning that the fiscal situation is unsustainable) and negative or close to zero in the remainder. They exceed 5 percent of GDP in Greece, Ireland, Portugal, Slovenia, Spain and the United Kingdom. The UK suffers from a large primary deficit in 2011 (-6.3 percent of $\left.\mathrm{GDP}^{6}\right)$ but it enjoys an interest rate that is close to its growth rate. The other countries of this group suffer from both primary deficits and a positive gap between the interest rate and the growth rate. At the other end of the spectrum, Hungary posts a large, negative tax gap resulting from a very large primary surplus (7.5 percent of GDP in 2011 according to autumn 2011's forecasts). In between, some countries (Finland, Italy) display a positive tax gap despite primary surpluses: their tax gaps result from their interest rates exceeding their growth rates.

At the four-year horizon, tax gaps are generally lower (the unweighed average is -0.4 percent of GDP, against 2.3 percent at the one-year horizon). This results from both optimistic fiscal prospects (that are from Convergence/Stability reports) and from tighter gaps between interest rates and growth rates. This is especially striking for the six countries with large one-year tax gaps mentioned above. At the four-year horizons, their tax gaps are all below 4 percent and in all but Greece and Ireland, they are below 3 percent (the tax gap even turns negative in the UK). Tax gaps in the other countries are either negative or less than 1.2 percent of GDP, with the exception of the Czech Republic $(+3.3$ percent).

At the fifty-year horizon, the interest rate is assumed to exceed the growth rate in all countries. Additionally, ageing-related expenditures are now taken into account. In the "on-the-fly" scenario, most tax gaps are back to positive territory. Interestingly, the group of countries with tax gaps abote 4 percent includes Luxembourg, Malta, Luxembourg and Slovakia. Spain is also part of this group, but Greece and Ireland are below 4 percent (3.8 and 2.5, respectively), the UK is balanced and Portugal and Slovenia display negative tax gaps. Unsurprisingly, the "adjustment" scenario reduce the tax gaps at the 50-year horizon. La majority of them become negative.

The comparison with EC and IMF calculations is not easy since both the concepts of tax gaps and the underlying assumptions (e.g. about interest and growth rates) differ. Our one-year ahead tax gaps are highly correlated (more than 75 percent) with both EC and IMF tax gaps. The correlations drop to around 50 percent for the 4-year horizon and the 50-year "on-the-fly" one. It further drops to 22-29 percent for the 50-year "adjustment" scenario, which makes sense since neither the EC nor the IMF assume further reforms to tackle ageing-related spending. On the whole, we consider our calculations meaningful enough to proceed to the next steps of the analysis, which consist in incorporating the implicit liabilities related to SIFIs into our tax gaps. ${ }^{7}$

\footnotetext{
${ }^{6}$ see EC's forecasts of Autumn 2011.

${ }^{7}$ It should be reminded here that the aim of the paper is less to asses the fiscal sustainability of individual Member states than to evaluate the impact of accounting for banking risks in such assessment.
} 


\section{Contingent liabilities related to SIFIs}

From end 2007 to end 2010, the Irish government debt-to-GDP ratio jumped from 25 to 96 percent, and Ireland experienced a deep sovereign debt crisis. Still, before the crisis, this country had displayed fiscal balance and not raised any sustainability concern. ${ }^{8}$ The reason for this sudden change has to do with the collapse of the Irish banking sector and the decision to bail it out to avoid a major financial crisis. This experience suggests that age-related spending is not the only significant off-balance sheet item to be included in fiscal sustainability assessments. In this section, we intend to clarify the notion of contingent liability, before trying to incorporate it into our calculations of tax gaps.

\subsection{Contingent liabilities: concept and measurement}

Following, Polackova (1999) or Bank (1998), four types of government liabilities can be distinguished depending on whether they are explicit or implicit, direct or contingent. Explicit liabilities are enacted by a law or a contract, whereas implicit liabilities do not rely on any formal commitment but relate to a kind of moral (or unavoidable) obligation. In turn, direct liabilities will almost surely have to be honored in a predictable way, whereas the payment of contingent liabilities is conditional on the occurrence of a specific event outside the control of the debtor (see also Cebotari (2008)).

Only direct, explicit liabilities are recorded in the national accounting system. As discussed above, ageing-related expenditures are off-balance sheet. Except for civil-servant pensions which are explicit, they can be classified direct, implicit liabilities. Examples of contingent liabilities include state guarantees (explicit), public-private partnerships (explicit), compensations for environmental catastrophes (implicit) or the support of ailing banks (implicit). ${ }^{9}$ Because they are by nature unpredictable, they are more difficult to evaluate ex ante. Still, as argued by Abbey (2001), there is a temptation for the government to extend generous explicit or implicit guarantees that bear political reward at no cost in the short run.

Different strategies have been proposed in the literature to measure the risk and associated amounts of government contingent liabilities (see Polackova (1999), Bank (1998), Hemming (2006), Currie \& Velandia (2002) for instance).

Concerning the measure of risk, the most simple approach is that of the European Commission (European Commission (2009)), based on composite indicators covering macro-financial risk and short-term rigidities on the top of more traditional fiscal variables. This approach however does not provide an evaluation of the costs incurred by the government under the bad state of nature,

\footnotetext{
${ }^{8}$ See, e.g., European Commission, Public Finances in EMU, 2007: "[...] in 11 countries - Belgium, Bulgaria, Denmark, Estonia, Ireland, Spain, Cyprus, the Netherlands, Austria, Finland and Sweden - the current fiscal position would be consistent with sustainable public finances if there was no impact of ageing on public finances" (p. 58).

${ }^{9}$ Note that the cost incurred in the case of a bank crisis is partly explicit, e.g. deposit insurance schemes.
} 
neither does it provide a probability. To fully evaluate contingent liabilities, it is necessary to combine probabilities with costs. Two alternative avenues can be followed. The first one is to measure contingent liabilities as the mathematical expectation of the present value of costs (probability of occurrence $\times$ cost in occurrence), or as the present value of the "maximum probable loss" (valueat-risk approach, see Currie (2002)). Probabilities and losses can be estimated based on historical data. To recover the variance of the costs, one option is to use Monte Carlo simulations (see Hemming (2006) for instance). The second approach relies on option prices: a government guarantee can be considered as a "put" option (see Merton (1977), Cebotari (2008)), so the contingent liability can be recovered based on the price of this option.

\subsection{Contingent liabilities and fiscal sustainability: a micro- based approach}

In this section, we intend to incorporate a micro-based measure of contingent liabilities of European governments related to their SIFIs into the tax gap described in Section 2. To measure contingent liabilities, we rely on the consistent - although debated - stress tests of 90 banks (considered "systemic") in 21 countries released by the European Banking Authority in July 2011 (see European Banking Authority (2011)). The scenario of stress includes haircuts (with associated probabilities) on sovereign debts affecting the trading book, a fall in housing prices, a downturn in growth, and a depreciation of the USD (see Appendix 3 of the EBA report). The impact on each bank's balance sheet is then calculated for 2011 and 2012.

We rely on the difference between the Risk-Weigthed Asset (RWA) of each bank and the value of core tier 1 capital denoted $K$. For each bank, the exposure of the government is then $X=R W A-K$, which measures the risk not covered by core capital. ${ }^{10}$ We finally sum up all exposures to individual banks at the country level.

It should be noted that, by summing up exposures to individual banks, we consider a pessimistic scenario where all systemic banks need simultaneously to be bailed out. Furthermore, the government is assumed to be the only source of recapitalization. Finally, the cost is considered definitive, whereas in some cases it can be at least partially recovered. ${ }^{11}$

Here we concentrate on the tax gap at the four-year horizon. Consistently, we need to introduce government exposure to systemic banking risk, $X$, for the next four years (here 2011 to 2014). Given the lack of forward-looking data, we consider $X$ to be a fixed proportion of GDP which we denote by $x$ and calculate for 2011 based on EBA data for costs and European Commission forecasts for

\footnotetext{
${ }^{10}$ We use the full static balance sheet assumption here. Like European Commission (2011), we assume that bank losses are first absorbed by core capital. However, European Commission (2011) uses an in-house model of bank default probability, whereas we directly use the EBA estimation of RWAs. We have checked that RWA never exceeds the total of the bank's assets.

${ }^{11}$ In the case of Sweden in the $1990 \mathrm{~s}$, for instance, the final cost for the taxpayer was negligible, see Laeven \& Valencia (2008).
} 
GDPs.

To calculate the expected costs of banking crises over the next four years, we need to combine $x$ with a probability of crisis at each period. We consider the instantaneous probability of a crisis $p$ as a parameter (ranging from 0 to $10 \%$ ), and assume that when a banking crisis appears in a country, it has no chance to appear again during the three following years. We therefore model the probability process as a binomial tree, stopping whenever a crisis occurs. Without discounting future losses, ${ }^{12}$ we get:

$$
\begin{aligned}
\mathbb{E}(\text { cost }) & =p x+p(1-p) x+p(1-p)^{2} x+p(1-p)^{3} x \\
& =p x \sum_{s=1}^{4}(1-p)^{s-1}
\end{aligned}
$$

The expected recapitalization costs are finally incorporated into the mediumrun tax gap detailed in Section 2. More specifically, we add the annualized expected cost of a crisis to the average spending ratios in Equation (13). The results are reported in Table 2 . The first column $(p=0 \%)$ recalls the results obtained without accounting for the exposure of the government to systemic banking crises. The next two columns report the results for an instantaneous probability of five and ten percent, successively. The final column reports the cost of a bailout independently from its probability.

Unsurprisingly, the cost of a bailout, relative to GDP, is higher in countries where bank balance sheets are large relative to GDP: the cost exceeds 100 percent of GDP in Cyprus, Spain, Ireland, the Netherlands, Portugal, Sweden and the United Kingdom. In these countries, even a 5 percent instantaneous probability of a banking crisis has a dramatic impact on the tax gap. The latter rises by 13.3 percentage points between he first two columns in Cyprus, $7.7 \mathrm{pp}$ in Spain, $5.6 \mathrm{pp}$ in Ireland, $4.8 \mathrm{pp}$ in the Netherland, $5.8 \mathrm{pp}$ in Portugal, $6.0 \mathrm{pp}$ in Sweden and $5.8 \mathrm{pp}$ in the UK. With a 10 percent instantaneous probability of a crisis, all these countries display tax gaps exceeding 6 percent, and four of them are double-digit. It should be noted also that even in countries with a more limited cost in the case of a crisis, the impact of accounting for a crisis event is significant. For instance, the German tax gap rises by $2.1 \mathrm{pp}$ when accounting for a 5 percent probability of a crisis. The Finish tax gap rises by $1.0 \mathrm{pp}$ although the cost of a bail out would be "only" $20.8 \%$ of GDP in this country.

\subsection{Contingent liabilities and fiscal sustainability: an al- ternative micro-based approach}

Obviously, the figures obtained in the previous section are very large due to extreme assumptions concerning the amount of the bail-out in the case of a

\footnotetext{
${ }^{12}$ Discounting future losses affects marginally the results at the four-year horizon, see Blanchard (1990).
} 
Table 2: Four-year tax gaps with exposure to banking crises, micro-based, EBA approach

\begin{tabular}{r|ccc|c}
\hline & \multicolumn{3}{|c|}{ Tax gap with micro-based } & Micro-based cost \\
& \multicolumn{2}{|c}{ crisis costs, in percent } & \\
& $p=0 \%$ & $p=5 \%$ & $p=10 \%$ & $x_{i}$ (\% of GDP) \\
\hline AT & 0.2 & 3.8 & 6.9 & 77.9 \\
BE & -0.5 & 2.4 & 4.9 & 63.2 \\
CY & 1.1 & 14.4 & 25.7 & 287.0 \\
DE & -2.4 & -0.3 & 1.5 & 44.7 \\
DK & 0.8 & 5.1 & 8.9 & 94.5 \\
EL & 3.9 & 7.9 & 11.4 & 87.8 \\
ES & 2.3 & 10.0 & 16.7 & 167.5 \\
FI & -2.2 & -1.2 & -0.4 & 20.8 \\
FR & 0.2 & 4.5 & 8.0 & 90.7 \\
HU & -11.7 & -10.5 & -9.6 & 24.2 \\
IE & 3.8 & 9.4 & 14.1 & 119.3 \\
IT & -0.5 & 2.5 & 5.1 & 64.6 \\
LU & -3.2 & -1.9 & -0.8 & 28.4 \\
MT & -0.7 & 1.5 & 3.5 & 48.9 \\
NL & 0.1 & 4.9 & 9.0 & 103.0 \\
PL & 0.0 & 0.4 & 0.8 & 8.8 \\
PT & 1.1 & 6.9 & 11.9 & 125.6 \\
SE & -4.3 & 1.7 & 6.8 & 129.1 \\
SI & 0.2 & 2.7 & 4.9 & 54.8 \\
UK & -2.0 & 3.8 & 8.7 & 125.1 \\
\hline
\end{tabular}

Source: Author's calculations based on EBA data. 
systemic bank crisis (indeed, we implicitly assume that the value of the RWA collapses to zero). Another approach is to rely on Acharya et al. (2010) and Acharya (2011) who propose a measure of how much capital would a bank need in the case of a financial crisis. Their methodology proceeds in two steps. First, they estimate the long run marginal expected shortfall in percent (LRMES), in the case of a $40 \%$ decline in market returns, which they consider the threshold of a financial crisis. ${ }^{13}$ Second, they calculate the capital shortage in case of a financial crisis, $S R I S K$, depending on existing bank liabilities:

$$
S R I S K=k(D+(1-L R M E S) E)-(1-L R M E S) E
$$

where $k$ represents the prudential standard ratio, taken as capital the ratio of the safest banks during the $2007-08$ crisis $(k=8 \%), D$ is the nominal debt of the bank and $E$ is its nominal equity. The result is available for 100 global financial institutions on the website of the Volatility Laboratory of New York University (V-Lab). ${ }^{14}$ Here we use a selection of 55 European banks considered as "systemic" according to the European Banking Agency. ${ }^{15}$ We use the last figure of SRISK in 2011, in USD million, and convert it into EUR bn by applying a 1.2939 exchange rate. We then follow the same methodology as in the previous section: for each country, we sum up available measures of SRISK, across the different banks, divide this sum by GDP and use this ratio as $x$ in Equation (14). The results are reported in Table 3. The last column reports the bank coverage per country. For two countries (Luxembourg and Slovenia), our V-Lab data does not include any bank. For two other countries (Germany, Spain), the coverage is relatively limited. ${ }^{16}$ For 12 countries, however, Table 3 can directly be compared with Table 2 since they cover the same banks at the date.

Not surprisingly given the methodology, the costs reported in Table 3 are much lower than those of Table 2. They pick at 32 percent of GDP for Cyprus, instead of 287 percent in Table $2 .{ }^{17}$ Consistently, the impact of the banking risk on the tax gaps is much reduced. For a 5 percent risk, the tax gap increases by $1 \mathrm{pp}$ or more in four countries: Cyprus, Sweden, the UK and France. It increases by $0.9 \mathrm{pp}$ in the Netherlands despite the calculation accounting for only half of the systemic banks. These figures are not negligible. For a 10 percent crisis probability, the tax gap is increased by another percentage point, approximately.

\footnotetext{
${ }^{13}$ They do so by extrapolating the equity losses estimated for a $2 \%$ decline in market returns. 14 vlab.stern.nyu.edu.

${ }^{15}$ We are grateful to Rob Capellini for making the data available to us. Unfortunately, not all 90 EBA's systemic banks are covered by V-Lab.

${ }^{16}$ For these two countries, the EBA provides data for an especially large number of banks: 12 for Germany and 25 for Spain.

${ }^{17}$ Interestingly, though, the correlation between $X$ and $S R I S K$ over the 55 bank sample is 89 percent. Hence the ranking of the risks is similar.
} 
Table 3: Four-year tax gaps with exposure to banking crises, micro-based, VLab approach

\begin{tabular}{r|ccc|c|c}
\hline & \multicolumn{3}{|c|}{ Tax gap with micro-based } & Micro-based cost & \\
& $p=0 \%$ & $p=5 \%$ & $p=10 \%$ & $x_{i}$ (\% of GDP) & Bank coverage (\%) \\
\hline AT & 0.2 & 0.6 & 1.0 & 9.7 & 100 \\
BE & -0.5 & 0.2 & 0.8 & 16.1 & 100 \\
CY & 1.1 & 2.6 & 3.8 & 32.1 & 100 \\
DE & -2.4 & -1.9 & -1.5 & 9.8 & 25 \\
DK & 0.8 & 1.4 & 2.0 & 14.6 & 75 \\
EL & 3.9 & 4.4 & 4.9 & 11.5 & 100 \\
ES & 2.3 & 2.9 & 3.5 & 14.3 & 32 \\
FI & -2.2 & -2.1 & -2.1 & 1.3 & 100 \\
FR & 0.2 & 1.2 & 2.0 & 20.0 & 75 \\
HU & -11.7 & -11.6 & -11.6 & 1.4 & 100 \\
IE & 3.8 & 4.3 & 4.7 & 10.4 & 100 \\
IT & -0.5 & 0.0 & 0.4 & 10.0 & 00 \\
LU & -3.2 & -3.2 & -3.2 & na & 100 \\
MT & -0.7 & -0.7 & -0.7 & 0.7 & 50 \\
NL & 0.1 & 1.0 & 1.7 & 18.1 & 100 \\
PL & 0.0 & 0.0 & 0.0 & -0.2 & 75 \\
PT & 1.1 & 1.5 & 1.9 & 9.6 & 0 \\
SE & -4.3 & -3.1 & -2.1 & 25.1 & 100 \\
SI & 0.2 & 0.2 & 0.2 & na & 00 \\
UK & -2.0 & -0.8 & 0.3 & 26.9 & \\
\hline
\end{tabular}

Source: Author's calculations based on V-Lab data. na: non-available. 


\section{Contingent liabilities and fiscal sustainability: a macro-based approach}

One limitation of the micro-based analysis of contingent liabilities is that it relies on a specific assessment of banking risks, based on the EBA or V-Lab methodology for a specific year, hence it lacks generality. Additionally, the micro-based approach should be considered a pessimistic scenario where all the SIFIs of a country need simultaneously to be bailed out by the government, with no recovery of the costs incurred in the later years. Another way of assessing fiscal sustainability is to rely on historical data on banking crises. Here we rely on two databases covering a large number of countries from 1977 to 2007: Reinhart \& Rogoff (2010) for the frequency of banking crises, and Laeven \& Valencia $(2008,2010)$ for their fiscal cost.

We concentrate on systemic banking crises defined by Laeven and Valencia as "Significant signs of financial distress in the banking system [...], and significant banking policy intervention measures in response to significant losses in the banking system" (Laeven \& Valencia (2010), p. 6). These authors further quantify these events in the following way: "we consider a sufficient condition for a crisis episode to be deemed systemic when either a country's banking system exhibits significant losses resulting in a share of nonperforming loans above $20 \%$ or bank closures of at least $20 \%$ of the banking assets, or fiscal restructuring costs of the banking sector are sufficiently high exceeding $5 \%$ of GDP" (Laeven \& Valencia (2010), pp. 6-7). They identify 124 episodes of such crises. The end of a crisis is defined as "the year before two conditions hold: real GDP growth and real credit growth are positive for at least two consecutive years". They also truncate crisis duration at 5 years to "keep the rule simple" (Laeven \& Valencia (2010), p. 10).

Among the 124 crises identified by Laeven and Valencia, we eliminate those not included in Reinhart \& Rogoff (2010)'s database, which leaves us with 60 systemic crises involving 51 different countries from 1977 to 2007. This database of systemic banking crises is then inserted into the wide database of Reinhart \& Rogoff (2010) to get a set of 2,158 observations between 1977 and $2007 .{ }^{18}$ On this sample, the unconditional probability of a systemic banking crisis is 2.78 percent (60 events out of 2,158 observations).

The fiscal cost of systemic banking crises is taken from Laeven and Valencia (see the methodology in Andrews et al. (2004) and Honohan \& Laeven (2005)). We use the gross fiscal cost in percent of GDP, which is defined as: "the outlays of the government and central bank in terms of bond issuance and disbursement from the treasury for liquidity support, payout of guarantees on deposits, costs of recapitalization and purchase of non performing loans" (p. 4 of Andrews et al. (2004)) from the outbreak of the crisis to five years later. Instead of the gross cost, we could have taken the cost net of asset sales and debt repayments by recapitalized entities. However, we would then have departed substantially

\footnotetext{
${ }^{18}$ We exclude the 2007-09 banking crisis from the sample because the final (five-year ahead) cost cannot be assessed by the writing of this paper (see below).
} 
from our micro-based approach that focuses on gross costs. ${ }^{19}$ We get an average cost of 14.29 percent of GDP over our sample of 60 systemic banking crises.

As a first step, we can plug the unconditional probability of a crisis, $\bar{p}=2.78$ percent, and the average cost in case of a crisis, $\bar{x}=14.29$ percent of GDP in the methodology of the previous section to recover tax gaps at the four-year horizon. The results are reported in the second column of Table 9. The impact of accounting for banking crises on the tax gap is now much more limited - the maximum is $2.6 \mathrm{pp}$ in Luxembourg. The problem here is that each country is assumed to bear the same costs in the event of a banking crisis. Additionally, although no longer ad hoc (as in the previous case), the instantaneous probability of a crisis is assumed to be the same for all countries, which is a strong assumption. Both the probability and the cost may depend on certain characteristics of the countries such as growth, inflation, the exchange-rate regime or the development of the financial sector. In the following, we calculate conditional probabilities and costs based on an econometric estimation over our sample of crisis events.

\subsection{Systemic banking crisis: econometric methodology}

To explain both the probability of a systemic banking crisis and the fiscal cost in the event of a crisis, we rely on three groups of explanatory variables covering macroeconomic shocks, macrofinancial shocks and institutionnal factors, that all have been highlighted by the existing literature (see Detragiache \& DemirgucKunt (2005); Demirguc-Kunt \& Detragiache (1997, 1999), Caprio et al. (2010), and Hardy \& Pazarbasioglu (1999)). Unfortunately, due to data limitations, we were obliged to drop most financial variables. The retained variables are listed in Table $4 .{ }^{20}$ We were also obliged to reduce our whole sample of countries to only 73 countries (see the list in Appendix).

The level of GDP per capita (in US dollar) is used as an indicator of development, the M2/GDP ratio is a standard indicator of financial development, the short-term real interest rate refers to the refinancing cost of the banks, and the accumulation of foreign-exchange reserves can be viewed as a protec-

\footnotetext{
${ }^{19}$ Our measure of gross cost includes interest payments on the debts incurred by the government to tackle the crisis. However we consider of second order the additional interest payments related to the additional level of debt, which allows us to include the cost of banking crises directly as primary expenditures in our tax-gap calculations. Conversely, the gross fiscal cost excludes the cost of guarantees that have not been paid.

${ }^{20}$ The following variables were also tried: terms-of-trade variation, deposit interest rate (nominal and real), exchange-rate variation, inflation (GDP deflator), net lending/net borrowing to GDP, debt to GDP, private consumption to GDP, growth rate of real imports, current-account balance in percent of GDP, equity-price index, domestic claims to private sector in percent of GDP, growth of domestic credit, liquid reserves to total bank assets, total claims to broad money, foreign claims to broad money, growth of domestic claims to private sector in percent of GDP, private credit by deposit money banks in percent of GDP, private credit by deposit money banks and other financial institutions in percent of GDP, growth of foreign total liabilities in percent of GDP, growth of total reserves minus gold, banks capital to assets, growth of population, M3 to GDP, net foreign assets to GDP, over or undervaluation of local currency (PPP conversion factor to market exchange rate ratio), income-level dummies.
} 
Table 4: Variables used in the econometric analysis

\begin{tabular}{|c|c|c|c|c|}
\hline Variable name & Description & Source & & number of obs \\
\hline bank & $\begin{array}{l}\text { Dummy for banking crisis: } 1 \text { for the outbreak of a } \\
\text { systemic banking crisis, } 0 \text { otherwise }\end{array}$ & Leaven Valencia (2010) & & 2158 \\
\hline cost & $\begin{array}{l}\text { Gross fiscal cost of a systemic banking crisis. Re- } \\
\text { ported at the beginning of the crisis }\end{array}$ & Leaven Valencia (2010) & & 60 \\
\hline gdp_g & Real GDP growth & $\begin{array}{l}\text { IMF IFS and World } \\
\text { databases }\end{array}$ & Bank & 1996 \\
\hline gdppc_g & Real growth of GDP per capita & $\begin{array}{l}\text { IMF IFS and World } \\
\text { databases }\end{array}$ & Bank & 1996 \\
\hline rir & $\begin{array}{l}\text { Short term real interest rate: discount rate minus } \\
\text { GDP deflator change. Central bank interest rate } \\
\text { when missing }\end{array}$ & $\begin{array}{l}\text { IMF IFS and World } \\
\text { databases }\end{array}$ & Bank & 1696 \\
\hline currency & Dummy for currency crisis & Reinhart Rogoff (2010) & & 1653 \\
\hline contagion & $\begin{array}{l}\text { Contagion dummy: } 1 \text { if there is a banking crisis in } \\
\text { the same region (see below), } 0 \text { otherwise }\end{array}$ & & & 2158 \\
\hline gdppc_usd & GDP per capita in USD & World Bank database & & 1977 \\
\hline M2_GDP & Ratio of M2 in percent of GDP & WB database & & 1609 \\
\hline foreign_exch & Ratio of foreign exchange reserves to GDP & IMF IFS line $1 \mathrm{~d}$ & & 1884 \\
\hline geog & $\begin{array}{l}\text { Regional dummies: (1) East Asia and Pacific, (2) } \\
\text { Eastern Europe and Central Asia, (3) Latin Amer- } \\
\text { ica and the Caribbean, (4) Middle East, North } \\
\text { Africa and South Asia, (5) Sub-Saharan Africa, } \\
\text { (6) Western, Northern and Southern Europe, (7) } \\
\text { Other high income }\end{array}$ & World Bank database & & 2158 \\
\hline
\end{tabular}


tion against at least currency crises. We also add real GDP (or real GDP per capita) growth as a measure of the pre-crisis outlook. Note that all ratios and rates are expressed in percent of GDP or percentage points.

The currency-crisis dummy intends to catch the possibility of twin crises, that can be more costly than plain banking crises. We introduce seven geographic dummies based on World Bank and United Nations classifications to correct for the heterogeneity of the sample. ${ }^{21}$ A contagion dummy tries to take stock of the correlation of crises within a geographic area.

Because our fiscal cost database includes censored data, the most natural econometric approach is a tobit model with a binomial selection equation modeling the probability of a crisis outbreak. Although we are only interested in the outbreak itself, we cannot treat the years of continuation of the crisis as normal data. We therefore drop the corresponding rows of the sample until the crisis is over. Endogeneity is the second problem to solve: Demirguc-Kunt \& Detragiache (1997, 1999); Detragiache \& Demirguc-Kunt (2005) use a logit model with contemporaneous regressors. This methodology is problematic as the independent variables may be affected by the banking crisis. To avoid this issue, we lag all explanatory variables by one period.

Preliminary estimations of a tobit model showed insignificant correlation between the residuals of the selection equation and those of the outcome equation. We concluded the selection bias to be negligible and therefore decided to estimate the probability and the cost of banking crises separately through multinomial logit and OLS estimations, respectively. ${ }^{22}$

\subsection{Estimation results: probability of a crisis}

The first step is to estimate a binomial model where the dependent variable is a dummy for the crisis event. We assume logistic residuals and thus perform a binomial logit estimation. The results are reported in Table 5. The (lagged) real growth of GDP per capita always has significant, negative impact on the probability of the outbreak of a banking crisis. As reported in Table 6, a 1-pp increase in the growth rate reduces the probability of a crisis by approximately 6 percent. In Column (5), the growth of GDP per capita is replaced by the growth of GDP. The latter variable also has significant, negative, although more limited impact on the probability of a crisis. Foreign-exchange reserves too have a significant, negative impact on the probability of a crisis: a high reserveto-GDP ratio tends to protect countries against the occurrence of a banking crisis. The lack of macrofinancial data does not allow us to further explore the channels of this relationship. Conversely, our contagion dummy does not appear

\footnotetext{
${ }^{21}$ Country dummies or fixed effects are not appropriate here due to the limited number of crisis events over our sample.

${ }^{22} \mathrm{~A}$ panel data, random or fixed-effect, logit estimation with simulated maximum likelihood and conditional logit models was also tried. The maximum likelihood estimations did not converge and the small number of countries experiencing a crisis reduced the sample to less than 700 rows. We also tried skewed logit regression and a log linear model specification, which are supposed to be more adapted to rare events, but the functional forms were rejected.
} 
significant, neither do our two measures of (financial) development (M2-to-GDP ratio and level of GDP per capita). Only the short-run real refinancing cost of banks has, the positive, expected impact on the probability of a crisis.

Table 5 and Table 6 (which reports the odd ratios) show the significant, negative and large impact of the "Other EU countries" dummy. It should be reminded at this stage that the 2007-09 crisis is not included in the sample. Although less systematically, the "Other OECD" and "Sub-Saharan Africa" dummies also bear significant, negative coefficients: other things equal, the probability of a crisis is lower in these regions than in South-East Asia - our benchmark in the estimation.

In order to evaluate our model, we follow the literature (Kaminsky (1998), Demirguc-Kunt \& Detragiache (1999)) and calculate its ability to signal crises one year ahead without too much noise. Denoting by $\theta$ the probability threshold above which a crisis signal is released, $a(\theta)$ the risk of missing a crisis (Type I error) and $b(\theta)$ the risk of a false alarm (Type II error), we select $\theta$ so as to minimize the following loss function:

$$
L(\theta)=c_{1}[(1-a(\theta)) w+b(\theta)(1-w)]+c_{2} a(T) w
$$

where $c_{1}$ is the costs associated with taking preventive action against a banking crisis, $c_{2}$ is the cost of a non-anticipated banking crisis, and $w$ is the unconditional probability of an outbreak of a crisis. $L(T)$ can be rearranged as:

$$
L(\theta)=w c_{1}\left[1+a(\theta) \frac{c_{2}-c_{1}}{c_{1}}+b(\theta) \frac{1-w}{w}\right]
$$

Like Demirguc-Kunt \& Detragiache (1999), we calculate $\theta$ and associated Type I and Type II errors with $c_{1}=1$ and, successively, $c_{2}=5,10$ or 20 . The results are reported in Table 7 . As usual in the literature on early warning indicators, the only way to raise the proportion of correctly predicted crises is to adopt a very low probability threshold, but then there is a large proportion of false alarms. Here, with $c_{2}=20$, the crisis signal is released when the probability of a crisis is higher than 4.3 percent. Then, the model correctly predicts 23 crises, but in 307 cases, the alarm is false. On the whole, the model performs poorly in predicting banking crises. However one reason for such poor prediction is the constraint of a unique threshold that will transform a crisis probability into a binary prediction. In the following, we are not interested in the predictions of the model but rather in the probability of a banking crisis itself, which will be combined with the fiscal cost in case of a banking crisis.

\subsection{Estimation results: cost of a crisis}

As already mentioned, we do not find any convincing evidence of a relationship between the selection equation (occurrence of a crisis) and the cost of a crisis. We therefore proceed to standard, OLS estimations of the logarithm of the

cost of crisis. The results are reported in Table 8. Both the lagged growth rate of GDP per capita and the lagged value of foreign-exchange reserves (as 
Table 5: Logit estimation results: probability of a crisis

\begin{tabular}{|c|c|c|c|c|c|c|c|}
\hline Variables & (1) & $(2)$ & (3) & (4) & (5) & (6) & (7) \\
\hline \multirow[t]{2}{*}{ gdppc_g } & $-0.058 * *$ & $-0.054^{*}$ & $-0.058 * *$ & $-0.058^{* *}$ & & $-0.062^{*}$ & $-0.077^{* *}$ \\
\hline & $(0.026)$ & $(0.028)$ & $(0.027)$ & $(0.026)$ & & $(0.036)$ & $(0.033)$ \\
\hline \multirow[t]{2}{*}{ foreign_exch } & $-0.046^{* *}$ & $-0.045^{* *}$ & $-0.046^{* *}$ & $-0.046^{* *}$ & $-0.047^{* *}$ & $-0.029^{*}$ & $-0.046^{* *}$ \\
\hline & $(0.018)$ & $(0.018)$ & $(0.020)$ & $(0.019)$ & $(0.019)$ & $(0.016)$ & $(0.019)$ \\
\hline \multirow[t]{2}{*}{ contagion } & & 0.329 & & & & & \\
\hline & & $(0.298)$ & & & & & \\
\hline \multirow[t]{2}{*}{ M2_GDP } & & & -0.003 & & & & \\
\hline & & & $(0.005)$ & & & & \\
\hline \multirow[t]{2}{*}{ gdppc_usd } & & & & -0.011 & & & \\
\hline & & & & $(0.024)$ & & & \\
\hline \multirow[t]{2}{*}{ gdp_g } & & & & & $-0.047^{*}$ & & \\
\hline & & & & & $(0.024)$ & & \\
\hline \multirow[t]{2}{*}{ currency } & & & & & & 0.263 & \\
\hline & & & & & & $(0.379)$ & \\
\hline \multirow[t]{2}{*}{ rir } & & & & & & & $0.001 * *$ \\
\hline & & & & & & & $(0.001)$ \\
\hline \multirow[t]{2}{*}{ East. EU \& CA } & 0.093 & -0.008 & 0.070 & 0.043 & 0.038 & 0.025 & -0.013 \\
\hline & $(0.457)$ & $(0.455)$ & $(0.485)$ & $(0.472)$ & $(0.461)$ & $(0.556)$ & $(0.462)$ \\
\hline \multirow[t]{2}{*}{$\mathrm{LAC}$} & -0.385 & -0.525 & -0.525 & -0.434 & -0.317 & -0.355 & -0.729 \\
\hline & $(0.425)$ & $(0.406)$ & $(0.464)$ & $(0.448)$ & $(0.414)$ & $(0.443)$ & $(0.472)$ \\
\hline \multirow[t]{2}{*}{ MENA } & -0.360 & -0.310 & -0.423 & -0.388 & -0.317 & -0.453 & -0.726 \\
\hline & $(0.609)$ & $(0.618)$ & $(0.615)$ & $(0.610)$ & $(0.617)$ & $(0.796)$ & $(0.677)$ \\
\hline \multirow[t]{2}{*}{$\mathrm{SSA}$} & $-1.155^{* *}$ & $-1.198 * *$ & $-1.285^{* *}$ & $-1.226^{* *}$ & $-1.059^{*}$ & $-1.433^{*}$ & $-1.366^{* *}$ \\
\hline & $(0.545)$ & $(0.539)$ & $(0.554)$ & $(0.566)$ & $(0.549)$ & $(0.750)$ & $(0.541)$ \\
\hline \multirow[t]{2}{*}{ Other EU } & $-1.843^{* * *}$ & $-1.881^{* * *}$ & $-1.731^{* *}$ & $-1.726^{* * *}$ & $-1.869 * * *$ & $-2.068 * * *$ & $-2.149 * * *$ \\
\hline & $(0.522)$ & $(0.523)$ & $(0.682)$ & $(0.607)$ & $(0.521)$ & $(0.621)$ & $(0.568)$ \\
\hline \multirow[t]{2}{*}{ Other OECD } & $-2.298 * *$ & $-2.209 * *$ & $-2.333^{* *}$ & $-2.166^{* *}$ & $-2.286^{* *}$ & $-2.129 * *$ & $-2.215^{* *}$ \\
\hline & $(1.053)$ & $(1.063)$ & $(1.054)$ & $(1.045)$ & $(1.052)$ & $(1.065)$ & $(1.057)$ \\
\hline \multirow[t]{2}{*}{ cons } & $-2.279 * * *$ & $-2.388 * * *$ & $-2.045^{* * *}$ & $-2.199 * * *$ & $-2.248 * * *$ & $-2.518 * * *$ & $-2.062 * * *$ \\
\hline & $(0.358)$ & $(0.401)$ & $(0.455)$ & $(0.407)$ & $(0.362)$ & $(0.431)$ & $(0.364)$ \\
\hline Number of obs. & 1859 & 1859 & 1543 & 1859 & 1866 & 1531 & 1635 \\
\hline Pseudo $\mathrm{R}^{2}$ & 0.068 & 0.070 & 0.061 & 0.068 & 0.064 & 0.075 & 0.077 \\
\hline Wald p-value & 0.000 & 0.000 & 0.000 & 0.000 & 0.000 & 0.000 & 0.000 \\
\hline
\end{tabular}

Source: own calculations.

East. EU \& CA: Eastern EU and Central Asia ; LAC: Latin America \& Carribean ; MENA:

Middle-East \& North Africa ; SSA: Sub-Saharian Africa. 
Table 6: Logit odds ratios

\begin{tabular}{lc}
\hline gdppc_g & $0.926^{* *}$ \\
foreign_exch & $0.955^{* *}$ \\
rir & $1.001^{* *}$ \\
East. EU \& CA & 0.987 \\
LAC & 0.482 \\
MENA & 0.484 \\
SSA & $0.255^{* *}$ \\
Other EU & $0.117^{* * *}$ \\
Other OECD & $0.109^{* *}$ \\
\hline
\end{tabular}

The odds ratio provides the multiplicative effect of each variable on the probability of a crisis. For instance, example, a 1 pp increase in the growth rate of GDP per capita multiplies the base probability by 0.926 : the probability is reduced by $8 \%$ approximately. Source: own calculations.

Table 7: Crisis prediction performance of our Logit model

\begin{tabular}{|l|c|c|c|c|c|c|}
\hline & \multicolumn{2}{|c|}{$c_{2}=5$} & \multicolumn{2}{c|}{$c_{2}=10$} & \multicolumn{2}{c|}{$c_{2}=20$} \\
\hline & Crisis & No crisis & Crisis & No crisis & Crisis & No crisis \\
\hline Crisis predicted & 4 & 17 & 10 & 65 & 23 & 307 \\
No crisis predicted & 42 & 1572 & 36 & 1524 & 23 & 1282 \\
\hline$\theta$ & \multicolumn{2}{|c|}{0.107} & \multicolumn{2}{c|}{0.078} & \multicolumn{2}{c|}{0.043} \\
Type I error & \multicolumn{2}{|c|}{$91.3 \%$} & \multicolumn{2}{c|}{$78.3 \%$} & \multicolumn{2}{c|}{$50.0 \%$} \\
Type II error & \multicolumn{2}{|c|}{$1.1 \%$} & $4.1 \%$ & \multicolumn{2}{c|}{$19.3 \%$} \\
\hline
\end{tabular}

Reading: with $c_{2}=5$, the model predicts a crisis when the probability reaches 10 percent, which is never the case over our sample. Hence a few crises are predicted and there is a $91.3 \%$ risk of missing a crisis. The number of signals rises for higher values of $c_{2}$, but then the proportion of false alarms rises.

Source: own calculations. 
Table 8: OLS estimation results: cost of a crisis

\begin{tabular}{|c|c|c|c|c|c|c|}
\hline & (1) & $(2)$ & (3) & (4) & $(5)$ & (6) \\
\hline gdppc_g & $\begin{array}{l}0.055^{*} \\
(0.030)\end{array}$ & $\begin{array}{l}0.056^{*} \\
(0.030)\end{array}$ & $\begin{array}{c}0.068^{* *} \\
(0.032)\end{array}$ & $\begin{array}{c}0.046 \\
(0.032)\end{array}$ & $\begin{array}{l}0.058^{*} \\
(0.030)\end{array}$ & $\begin{array}{c}0.109^{* * *} \\
(0.036)\end{array}$ \\
\hline foreign_exch & $\begin{array}{l}0.053^{*} \\
(0.027)\end{array}$ & $\begin{array}{l}0.052^{*} \\
(0.027)\end{array}$ & $\begin{array}{l}0.055^{*} \\
(0.028)\end{array}$ & $\begin{array}{c}0.044 \\
(0.027)\end{array}$ & $\begin{array}{l}0.049^{*} \\
(0.027)\end{array}$ & $\begin{array}{c}0.063^{* *} \\
(0.029)\end{array}$ \\
\hline gdppc_usd & & $\begin{array}{l}-0.003 \\
(0.018)\end{array}$ & & & & \\
\hline M2_GDP & & & $\begin{array}{c}0.001 \\
(0.004)\end{array}$ & & & \\
\hline rir & & & & $\begin{array}{c}0.010 \\
(0.008)\end{array}$ & & \\
\hline contagion & & & & & $\begin{array}{c}0.410 \\
(0.264)\end{array}$ & \\
\hline currency & & & & & & $\begin{array}{l}0.589^{*} \\
(0.323)\end{array}$ \\
\hline cons & $\begin{array}{c}1.769^{* * *} \\
(0.237)\end{array}$ & $\begin{array}{c}1.789^{* * *} \\
(0.265)\end{array}$ & $\begin{array}{c}1.667^{* * *} \\
(0.283)\end{array}$ & $\begin{array}{c}1.764^{* * *} \\
(0.243)\end{array}$ & $\begin{array}{c}1.566^{* * *} \\
(0.268)\end{array}$ & $\begin{array}{c}1.323^{* * *} \\
(0.282)\end{array}$ \\
\hline Number of obs. & 54 & 54 & 51 & 45 & 54 & 41 \\
\hline Adjusted $\mathrm{R}^{2}$ & 0.138 & 0.121 & 0.155 & 0.139 & 0.161 & 0.298 \\
\hline Fisher p-value & 0.0086 & 0.0238 & 0.0121 & 0.0274 & 0.0081 & 0.0010 \\
\hline
\end{tabular}

Source: own calculations.

a proportion of GDP) have a significant, positive impact on the fiscal cost of a crisis. It should be reminded here that the regression is performed only on crisis events: although high growth and high foreign-exchange reserves reduce the probability of a crisis (see Table 5), once the crisis hits, these two variables tend to increase the cost of a crisis. A possible interpretation is that higher growth in the previous period may be related to a credit-based, bubble boom. As for foreign-exchange reserves, they are included in our measure of the cost of a crisis: more reserves allow the government to bear a higher cost.

Like for the logit regression, neither the level of GDP per capita nor the M2-to-GDP ratio have a significant impact on the cost of a crisis. Now, though, the currency-crisis dummy has a positive, significant impact on the fiscal cost of the banking crisis: whenever there is a currency crisis, the cost of the banking crisis rises by 0.6 percent. This can be explained by the currency mismatch between the asset side and the liability side of the banking sector, with more debts than assets in foreign currencies.

\subsection{Implications for debt sustainability}

We can now combine the logit and the OLS estimations to get the conditional expectation of fiscal costs related to the possible occurrence of a systemic banking crisis. For each year from 2011 to 2014, we calculate the probability of an 
outbreak of a banking crisis and the cost of such an event, for each country depending on the values of the explanatory variables of the logit and OLS models, successively. We then multiply the probabilities with the costs to obtain the mathematical expected cost. Assuming, again, that if the crisis hits at time $t$, there will not be any other outbreak of a crisis during the next three years, we have:

$$
\begin{aligned}
\mathbb{E}\left(\operatorname{cost}_{i, t}\right) & =\hat{x}_{i, t} \hat{p}_{i, t}+\hat{x}_{i, t+1} \hat{p}_{i, t+1}\left(1-\hat{p}_{i, t}\right) \\
& +\hat{x}_{i, t+2} \hat{p}_{i, t+2}\left(1-\hat{p}_{i, t+1}\right)\left(1-\hat{p}_{i, t}\right) \\
& +\hat{x}_{i, t+3} \hat{p}_{i, t+3}\left(1-\hat{p}_{i, t+2}\right)\left(1-\hat{p}_{i, t+1}\right)\left(1-\hat{p}_{i, t}\right)
\end{aligned}
$$

where $\hat{x}_{i, t}$ is the conditional estimation of the crisis cost for country $i$ at time $t$, and $\hat{p}_{i, t}$ is the conditional probability of a crisis. These two conditional estimates are calculated for $t=2011$ to 2014, based on the following assumptions:

- Growth of GDP per capita: IMF projections of September 2011 (World Economic Outlook);

- Foreign-exchange reserve ratio set at its end-2010 level;

- Two alternative scenarios depending on whether there is a currency crisis or not.

The expected cost of a banking crisis is ultimately incorporated into the tax gap of Section 2. The results are reported in Table 9. The first column $(p=0)$ recalls the tax gap obtained without accounting for banking crises. The second column $(\bar{p} \bar{x})$ shows the tax gaps with the unconditional probability and the unconditional cost. The next two columns $\left(\hat{p}_{i} \hat{x}_{i}\right)$ report the tax gaps when following the methodology just described, assuming no currency crisis ("No CC") and the occurrence of a currency crisis ("CC"), successively. For the sake of interpretation, we then report the conditional probability $\hat{p}_{i}$ and cost $\hat{x}_{i}$ for each country in turn, averaged over 2011-14. In the last column $\hat{p}_{i} x_{i}$, we use the conditional probabilities given by the logit model but rely on the micro-based evaluation of the costs in case of a crisis of Section 3.

Not surprisingly, the average estimated costs obtained from the macro-based approach are much lower and less diverse than those obtained from the microbased (EBA) approach: from 6 to 59 percent of GDP, compared to 9 to 287 percent of GDP when relying on EBA figures. The orders of magnitude are closer to the micro-based (V-Lab) approach. Nonetheless, those countries displaying high crisis costs according to the micro-based approach (Cyprus, the Netherlands, Sweden, the UK) do not display high cost according to the macrobased approach. A first, major reason for these discrepancies is that here we no longer assume that, in the event of a crisis, all the SIFIs of a country will have to be bailed out. Secondly, our database includes a minority of banking crises in advanced economies where the banking sector represents a large share of the economy. Thirdly, due to data limitations, we were unable to include proxies 
of financial vulnerability in our macro-based approach, concentrating on macro variables.

One major advantage of the macro-based approach is that it attributes a conditional probability to the possibility of a crisis. On average over 2011-14, these probabilities range from 0.5 percent in Denmark to 11.0 percent in Cyprus. This range validates ex post the different probabilities studied in the microbased approach. Interestingly, though, those countries with higher probabilities of crisis (Cyprus, Slovakia) would suffer relatively limited costs in the event of a crisis (less than 10 percent of GDP). Conversely, in Hungary and Romania, the probability of a crisis is limited but the cost in the case of a crisis is relatively high. On the whole, the combined effect of probabilities and macro-based costs is found very limited, except in new member states where the the cost in the case of a crisis is found much higher than in the other member states.

It is then tempting to combine our estimated crisis probabilities to the costs recovered from the micro (EBA) approach. ${ }^{23}$ The tax gaps are increased by around one pp or less. A major exception is Cyprus, with a tax gap rising from 1.6-2.2 percent of GDP (macro-based approach) to 27.9 percent. Interestingly, the tax gaps obtained from unconditional probabilities and risks (second column of Table 9) are found in-between the pure macro-based approach (with conditional probabilities and costs) and the hybrid, micro-macro approach (macrobased, conditional probabilities with micro-based costs). Again, Cyprus is the exception.

\section{Conclusion}

We have proposed an attempt to include the contingent liabilities arising from too-big-to-fail banks into a standard, tax-gap assessment of fiscal sustainability. To do so, we have followed two alternative routes. The first one relies of microeconomic data at the bank level either collected and released by the European Banking Authority in the occasion of its second wave of stress tests (July 2011), or calculated by the Volatility Laboratory of New York University. The second one relies on econometric estimations of the probability and the cost of a systemic banking crisis, based on historical data gathered by and Laeven \& Valencia $(2008,2010)$ and Reinhart \& Rogoff $(2010)$. The former approach tends to maximize the fiscal cost of systemic banking crises since it assumes that in the event of a crisis, all SIFIs would need to be bailed out by the government. In turn, the latter approach tends to minimize the fiscal cost as it relies on historical data involving a limited number of countries where the banking sector represents a large share of the economy, and it tends to neglect financial fragilities. Hence we believe that the combined use of these two methodologies helps to measure the range of fiscal risk.

${ }^{23}$ Here we select the EBA approach rather than the V-Lab one due to its extended coverage. 
Table 9: Four-year tax gaps in percent: a synthesis

\begin{tabular}{|c|c|c|c|c|c|c|c|}
\hline \multirow[t]{3}{*}{ Country } & \multirow{2}{*}{\multicolumn{4}{|c|}{$\begin{array}{l}\text { Tax gap with macro-based } \\
\text { costs ( } \% \text { of GDP) }\end{array}$}} & \multicolumn{2}{|c|}{ Average over 2011-14 } & \multirow{3}{*}{$\begin{array}{c}\text { Tax gap with micro-based } \\
\text { costs }(\% \text { of GDP }) \\
\hat{p}_{i} x_{i}\end{array}$} \\
\hline & & & & & proba ( & st $(\%$ of GDP) & \\
\hline & $p=0$ & $\bar{p} \bar{x}$ & $\hat{p}_{i} \hat{x}_{i}$, No CC & $\hat{p}_{i} \hat{x}_{i}, \mathrm{CC}$ & $\hat{p}_{i}$ & $\hat{x}_{i}$, No CC & \\
\hline AT & 0.2 & 0.6 & 0.3 & 0.3 & 1.2 & 7.7 & 1.1 \\
\hline $\mathrm{BE}$ & -0.5 & -0.2 & -0.5 & -0.4 & 1.2 & 7.2 & 0.2 \\
\hline BG & 0.4 & 0.8 & 1.7 & 2.7 & 2.3 & 58.7 & $\mathrm{n} / \mathrm{a}$ \\
\hline $\mathrm{CY}$ & 1.1 & 1.5 & 1.6 & 2.1 & 11.0 & 5.9 & 27.9 \\
\hline $\mathrm{CZ}$ & 3.3 & 3.7 & 4.3 & 5.1 & 4.1 & 25.5 & $\mathrm{n} / \mathrm{a}$ \\
\hline DK & 0.8 & 1.1 & 0.9 & 1.0 & 0.5 & 33.5 & 1.2 \\
\hline $\mathrm{EE}$ & -1.5 & -1.1 & -1.4 & -1.3 & 0.6 & 21.0 & $\mathrm{n} / \mathrm{a}$ \\
\hline FI & -2.2 & -1.8 & -2.1 & -2.0 & 1.1 & 8.4 & -1.9 \\
\hline FR & 0.2 & 0.6 & 0.3 & 0.4 & 1.3 & 7.0 & 1.4 \\
\hline $\mathrm{DE}$ & -2.4 & -2.0 & -2.3 & -2.2 & 1.2 & 8.0 & -1.9 \\
\hline EL & 3.9 & 4.3 & 3.9 & 4.0 & 1.8 & 4.5 & 5.4 \\
\hline HU & -11.7 & -11.3 & -10.4 & -9.6 & 2.3 & 56.3 & -11.1 \\
\hline IE & 3.8 & 4.2 & 3.9 & 4.0 & 1.4 & 6.0 & 5.5 \\
\hline IT & -0.5 & -0.1 & -0.4 & -0.4 & 1.3 & 6.5 & 0.3 \\
\hline LV & -1.8 & -1.4 & -0.6 & 0.4 & 2.5 & 53.3 & $\mathrm{n} / \mathrm{a}$ \\
\hline LT & 1.3 & 1.7 & 2.3 & 3.1 & 3.9 & 28.3 & $\mathrm{n} / \mathrm{a}$ \\
\hline $\mathrm{LU}$ & -3.2 & -2.8 & -3.1 & -3.1 & 1.3 & 6.8 & -2.9 \\
\hline MT & -0.7 & -0.4 & -0.6 & -0.6 & 1.1 & 8.6 & -0.2 \\
\hline NL & 0.1 & 0.5 & 0.2 & 0.2 & 1.28 & 6.8 & 1.4 \\
\hline PL & 0.0 & 0.4 & 1.0 & 1.6 & 3.79 & 28.5 & 0.3 \\
\hline $\mathrm{PT}$ & 1.1 & 1.5 & 1.2 & 1.2 & 1.47 & 5.7 & 2.9 \\
\hline RO & 1.1 & 1.5 & 2.4 & 3.1 & 3.12 & 44.3 & $\mathrm{n} / \mathrm{a}$ \\
\hline SK & -0.7 & -0.3 & -0.1 & 0.5 & 8.77 & 8.4 & $\mathrm{n} / \mathrm{a}$ \\
\hline SI & 0.2 & 0.5 & 0.2 & 0.3 & 1.21 & 7.4 & 0.8 \\
\hline ES & 2.3 & 2.7 & 2.4 & 2.4 & 1.34 & 6.4 & 4.5 \\
\hline SE & -4.3 & -3.9 & -4.2 & -4.1 & 0.73 & 15.1 & -3.4 \\
\hline UK & -2.0 & -1.7 & -1.9 & -1.9 & 1.23 & 7.2 & -0.5 \\
\hline
\end{tabular}

$\overline{\mathrm{CC}}=$ Currency crisis; $\mathrm{n} / \mathrm{a}$ : non available.

Source: own calculations. 
Depending on the measure of the costs (either micro or macro) and on the data source, we find contrasted impact of the banking risk on the tax gap of the different countries under review, ranging from a few tenths of percentage points (macro-base approach for "old" member states) to several percentage points (micro-based, EBA approach). In-between, the micro-based (V-Lab) approach suggests that systemic banking risk could raise tax gaps by around one percentage point.

Our work cannot easily be compared with the inclusion of age-related implicit and explicit liabilities. In the case of ageing, the cost is relatively limited but the probability is close to unity. In the case of a systemic banking crisis, the probability is limited but the cost can be very high. This suggests to complement our expected-cost analysis with a value-at-risk analysis. However, it is already difficult to estimate the probability of a systemic banking crisis based on a limited number of events. Recovering the whole distribution of costs in order to perform a value-at-risk analysis cannot be envisaged. The solution then would be to perform stress tests, e.g. to calculate the impact of the worstcase scenario on the tax gap, with a unitary probability. However, given the amounts involved (even in the macro-based case), tax gaps would no longer provide any information on fiscal sustainability. Rather, this approach would point to the needs to avoid any implicit government insurance granted to SIFIs, except maybe after the building up of a dedicated fund financed through the SIFIs themselves and/or restricting such insurance to part of banking activities.

More generally, our work illustrates the limits of stress testing. In the case of a very detrimental scenario, fiscal sustainability can be at risk whatever the initial surplus; or a bank can go bankrupt whatever its initial ratio of core capital. The orders of magnitude suggest to search for ways to circumvent the sustainability issue in case of a catastrophic event through reducing the probability and the cost of the catastrophic event itself. 


\section{Appendix}

Country sample

\begin{tabular}{|c|c|c|c|}
\hline Country & $\begin{array}{l}\text { Number of crises } \\
\text { (with fiscal costs) }\end{array}$ & Country & $\begin{array}{l}\text { Number of crises } \\
\text { (with fiscal costs) }\end{array}$ \\
\hline Angola & 0 & Latvia & 1 \\
\hline Argentina & 4 & Lithuania & 1 \\
\hline Australia & 0 & Macedonia & 1 \\
\hline Austria & 0 & Malaysia & 1 \\
\hline Belgium & 0 & Mauritania & 1 \\
\hline Benin & 1 & Mexico & 1 \\
\hline Bolivia & 1 & Myanmar & 0 \\
\hline Brazil & 2 & Netherlands & 0 \\
\hline Bulgaria & 1 & New Zealand & 0 \\
\hline Canada & 0 & Nicaragua & 1 \\
\hline Chile & 1 & Norway & 1 \\
\hline China, P.R. & 1 & Paraguay & 1 \\
\hline Colombia & 2 & Philippines & 2 \\
\hline Côte d'Ivoire & 1 & Poland & 1 \\
\hline Croatia & 1 & Portugal & 0 \\
\hline Czech Republic & 1 & Romania & 1 \\
\hline Denmark & 0 & Russia & 1 \\
\hline Dominican Republic & 1 & Senegal & 1 \\
\hline Ecuador & 1 & Singapore & 0 \\
\hline Estonia & 1 & Slovenia & 1 \\
\hline Finland & 1 & South Africa & 0 \\
\hline France & 0 & Spain & 1 \\
\hline Germany & 0 & Sri Lanka & 1 \\
\hline Ghana & 1 & Sweden & 1 \\
\hline Greece & 0 & Switzerland & 0 \\
\hline Guatemala & 0 & Tanzania & 1 \\
\hline Honduras & 0 & Thailand & 2 \\
\hline Hungary & 1 & Tunisia & 1 \\
\hline Iceland & 0 & Turkey & 2 \\
\hline Indonesia & 1 & Ukraine & 1 \\
\hline Ireland & 0 & United Kingdom & 0 \\
\hline Israel & 1 & United States & 1 \\
\hline Italy & 0 & Uruguay & 2 \\
\hline Jamaica & 1 & Venezuela & 1 \\
\hline Japan & 1 & Vietnam & 1 \\
\hline Jordan & 1 & Zambia & 1 \\
\hline Korea & 1 & & \\
\hline
\end{tabular}


Systemic Banking Crises

\begin{tabular}{lccc|lccc}
\hline Country & $\begin{array}{c}\text { Start } \\
\text { date }\end{array}$ & $\begin{array}{c}\text { End } \\
\text { date }\end{array}$ & $\begin{array}{c}\text { Fiscal Cost } \\
\text { (\% of GDP) }\end{array}$ & Country & $\begin{array}{c}\text { Start } \\
\text { date }\end{array}$ & $\begin{array}{c}\text { End } \\
\text { date }\end{array}$ & $\begin{array}{c}\text { Fiscal Cost } \\
\text { (\% of GDP) }\end{array}$ \\
\hline \hline Argentina & 1980 & 1982 & 55.1 & Macedonia & 1993 & 1995 & 32 \\
Argentina & 1989 & 1991 & 6 & Malaysia & 1997 & 1999 & 16.4 \\
Argentina & 1995 & 1995 & 2 & Mauritania & 1984 & 1984 & 15 \\
Argentina & 2001 & 2003 & 9.6 & Mexico & 1994 & 1996 & 19.3 \\
Benin & 1988 & 1992 & 17 & Nicaragua & 2000 & 2001 & 13.6 \\
Bolivia & 1994 & 1994 & 6 & Norway & 1991 & 1993 & 2.7 \\
Brazil & 1990 & 1994 & 0 & Paraguay & 1995 & 1995 & 12.9 \\
Brazil & 1994 & 1998 & 13.2 & Philippines & 1983 & 1986 & 3 \\
Bulgaria & 1996 & 1997 & 14 & Philippines & 1997 & 2001 & 13.2 \\
Chile & 1981 & 1985 & 42.9 & Poland & 1992 & 1994 & 3.5 \\
China. P.R & 1998 & 1998 & 18 & Romania & 1990 & 1992 & 0.6 \\
Colombia & 1982 & 1982 & 5 & Russia & 1998 & 1998 & 6 \\
Colombia & 1998 & 2000 & 6.3 & Senegal & 1988 & 1991 & 17 \\
Côte d'Ivoire & 1988 & 1989 & 25 & Slovenia & 1992 & 1992 & 14.6 \\
Croatia & 1998 & 1999 & 6.9 & Spain & 1977 & 1981 & 5.6 \\
Czech Republic & 1996 & 2000 & 6.8 & Sri Lanka & 1989 & 1991 & 5 \\
Dominican Rep & 2003 & 2004 & 22 & Sweden & 1991 & 1995 & 3.6 \\
Ecuador & 1998 & 2002 & 21.7 & Tanzania & 1987 & 1988 & 10 \\
Estonia & 1992 & 1994 & 1.9 & Thailand & 1983 & 1983 & 0.7 \\
Finland & 1991 & 1995 & 12.8 & Thailand & 1997 & 2000 & 43.8 \\
Ghana & 1982 & 1983 & 6 & Tunisia & 1991 & 1991 & 3 \\
Hungary & 1991 & 1995 & 10 & Turkey & 1982 & 1984 & 2.5 \\
Indonesia & 1997 & 2001 & 56.8 & Turkey & 2000 & 2001 & 32 \\
Israel & 1977 & 1977 & 30 & Ukraine & 1998 & 1999 & 0 \\
Jamaica & 1996 & 1998 & 43.9 & United States & 1988 & 1988 & 3.7 \\
Japan & 1997 & 2001 & 14 & Uruguay & 1981 & 1985 & 31.2 \\
Jordan & 1989 & 1991 & 10 & Uruguay & 2002 & 2005 & 20 \\
Korea & 1997 & 1998 & 31.2 & Venezuela & 1994 & 1998 & 15 \\
Latvia & 1995 & 1996 & 3 & Vietnam & 1997 & 1997 & 10 \\
Lithuania & 1995 & 1996 & 3.1 & Zambia & 1995 & 1998 & 1.4 \\
\hline & & & & & & & \\
\hline
\end{tabular}




\section{References}

Abbey, J. (2001). Fiscal irresponsibility and fiscal illusion. Centre for Policy Analysis.

Acharya, V. (2011). Measuring and Managing Global Systemic Risk. Presentation, NYU Stern School of Business - VLAB.

Acharya, V., Dreschler, I., \& Schnabl, P. (2011). A Pyrrhic Victory? Bank Bailouts and Sovereign Credit Risk. NBER Working Papers 17136, National Bureau of Economic Research, Inc.

Acharya, V. V., Pedersen, L. H., Philippon, T., \& Richardson, M. (2010). Measuring Systemic Risk. Mimeo, New York University.

Andrews, M., Piris Chavarri, A., Kawakami, Y., Frécaut, O., He, D., Hoelscher, D. S., Josefsson, M., Moretti, M., Quintyn, M., Taylor, M., \& Delgado, F.L. (2004). Managing Systemic Banking Crises. IMF Occasional Papers 224, International Monetary Fund.

Bank, W. (1998). Contingent liabilities: A threat to fiscal policy. PREMnotes - Economic policy.

Blanchard, O. J. (1990). Suggestions for a new set of fiscal indicators. OECD Economics Department Working Papers, (79).

Blanchard, O. J., Chouraqui, J.-C., Hagemann, R., \& Sartor, N. (1990). La soutenabilité de la politique budgétaire : nouvelles réponses à une question ancienne. Revue économique de l'OCDE.

Bohn, H. (1995). The sustainability of budget deficits in a stochastic economy. Journal of Money, Credit and Banking, 27(1), 257-271.

Caprio, G. J., D'Apice, V., Ferri, G., \& Puopolo, G. W. (2010). Macro Financial Determinants of the Great Financial Crisis: Implications for Financial Regulation. MPRA Paper 26088, University Library of Munich, Germany.

Cebotari, A. (2008). Contingent Liabilities: Issues and Practice. IMF Working Papers 08/245, International Monetary Fund.

Currie, E. (2002). The potential role of government debt management offices in monitoring and managing contingent liabilities. World Bank Report.

Currie, E. \& Velandia, A. (2002). Risk management of contingent liabilities within a sovereign asset-liability framework.

Demirguc-Kunt, A. \& Detragiache, E. (1997). The determinants of banking crises : evidence from industrial and developing countries. Policy Research Working Paper Series 1828, The World Bank. 
Demirguc-Kunt, A. \& Detragiache, E. (1999). Monitoring banking sector fragility : a multivariate logit approach with an application to the 1996-97 banking crises. Policy Research Working Paper Series 2085, The World Bank.

Detragiache, E. \& Demirguc-Kunt, A. (2005). Cross-Country Empirical Studies of Systemic Bank Distress: A Survey. IMF Working Papers 05/96, International Monetary Fund.

Domar, E. (1944). The burden of the debt and national income. The American Economic Review.

European Banking Authority (2011). EU-wide stress test aggregate report. Technical report, EBA.

European Commission (2009). Sustainability Report. Technical report.

European Commission (2010). Public Finances in EMU. Technical report.

European Commission (2011). Public Finances in EMU. Technical report.

Hamilton, J. \& Flavin, M. (1986). On the limitations of government borrowing: A framework for empirical testing. American Economic Review, 76(4), 80819.

Hardy, D. C. \& Pazarbasioglu, C. (1999). Determinants and leading indicators of banking crises: Further evidence. IMF Staff Papers, 46(3), 1.

Hemming, R. (2006). Public private partnerships, government guarantees and fiscal risk. IMF staff paper.

Honohan, P. \& Laeven, L., Eds. (2005). Systemic Financial Crises. Cambridge University Press.

Intgernational Monetary Fund (2011). Fiscal Monitor. Technical report.

Laeven, L. \& Valencia, F. (2008). Systemic Banking Crises: A New Database. IMF Working Papers 08/224, International Monetary Fund.

Laeven, L. \& Valencia, F. (2010). Resolution of Banking Crises: The Good, the Bad, and the Ugly. IMF Working Papers 10/146, International Monetary Fund.

Merton, R. C. (1977). An analytic derivation of the cost of deposit insurance and loan guarantees an application of modern option pricing theory. Journal of Banking $\&$ Finance, 1(1), 3-11.

Polackova, H. (1999). Contingent government liabilities: A hidden fiscal risk. Finance and Development, 36(1).

Reinhart, C. M. \& Rogoff, K. S. (2010). From Financial Crash to Debt Crisis. NBER Working Papers 15795, National Bureau of Economic Research, Inc. 